\title{
Internationalising Smart Specialisation: Assessment and Issues in the Case of EU New Member States
}

\author{
Slavo Radosevic ${ }^{1} \cdot$ Katerina Ciampi Stancova $^{2}$
}

Received: 20 October 2015 / Accepted: 17 November 2015 /

Published online: 28 November 2015

(C) The Author(s) 2015. This article is published with open access at Springerlink.com

\begin{abstract}
Smart specialisation is currently probably the largest innovation policy experiment in the world. Its aim is to move the EU less developed countries and regions on path of $\mathrm{R} \& \mathrm{D}$-based growth. This transformation requires not only endogenous knowledge and technology accumulation building but also coupling with international knowledge and production networks. Yet, internationalisation does not seem to be a crucial component in the design and development of Research and Innovation Strategies for Smart Specialisation (RIS3), which are at odds with the strong dependence of the EU New Member States (EU-13) on FDI and global value chains. Our analysis is grounded in the key 'stylised facts' related to EU-13 R\&D\&I activities, and the complex link between innovation and internationalisation. Innovation systems in the EU-13 are fragmented and based on largely public R\&D systems and on predominantly production-oriented foreign direct investment (FDI). This structural weakness calls for stronger support for innovation-oriented activities and for the integration of global value chains (GVCs) and FDI into local innovation systems. We explore the main obstacles to the internationalisation of smart specialisation and discuss ways to overcome them. We highlight the policy action areas related to providing support for technology upgrading in relation to the internationalisation of smart specialisation.
\end{abstract}

Keywords Inter-regional collaboration - Smart specialisation · Innovation policy · Transnational collaboration $\cdot($ Global) value chains $\cdot$ Regional development

The views expressed in this article are purely those of the author and cannot in any circumstances be regarded as stating an official position of the European Commission.

Katerina Ciampi Stancova

Katerina.CIAMPI-STANCOVA@ec.europa.eu

1 School of Slavonic and East European Studies (United Kingdom), University College London, London WC1E 6BT, UK

2 European Commission, JRC-IPTS, Seville, Spain 


\section{Introduction}

In a globalised economic environment, catching-up is about leveraging endogenous technology effort by exploiting foreign knowledge, technology and global networks (Fu et al. 2011). The EU-13 countries, the countries that joined the European Union (EU) after 2004, are catching up economies which need to combine local and foreign knowledge to leverage their innovation capabilities. Up to 2008, growth in the EU-13 could be characterised as finance-dependent and debt-intensive, based on externally financed consumption (consumer durables) (Becker et al. 2010). In these countries, foreign direct investment (FDI) plays an important role in growth and, especially, export (IMF 2013a). Post-2008, the challenge has been how to shift towards growth driven by investments and productivity improvements. This issue coincides with the aim of smart specialisation strategies, which is to ensure sustainable growth and convergence to EU income and productivity in these economies.

We assume that in order to upgrade technologically, the EU-13 will need to grow, based on local Research and Development and Innovation (R\&D\&I) efforts, and on the acquisition of foreign knowledge via FDI and R\&D networks. So far, FDI and global value chains (GVCs) have played important but quite differentiated roles in the EU-13 economies. FDI has increased productivity and export activity, but the spillovers from FDI have not been fully realised and remain rather localised (Hanousek et al. 2010; Damijan et al. 2013; Johannes 2006; Holland et al. 2000). Also, post-2008, there is a consensus that the EU-13, more than in the past, should draw on their local knowledge and skills and achieve market access via multinational enterprises (MNEs) and GVCs.

The approach to smart specialisation described in the Guide to Research and Innovation Strategies for Smart Specialisations (RIS3) by Foray et al. (2012) strongly promotes the international and trans-regional dimensions. In fact, internationalisation is considered 'a crucial component of smart specialisation strategy (S3)' (Foray et al., pp. 94). First, internationalisation within smart specialisation includes not only export and FDI but also 'strategic alliances, joint research, co-development, outsourcing, relocation, mergers and acquisitions, licensing intellectual property rights (IPR), soft landing, technology showcase' (Foray et al., p. 94). Second, internationalisation is a context within which regions should be able to identify 'niches' or specific domains for (present and future) competitive advantage, and relevant linkages and flows of goods, services and knowledge that reveal possible patterns of integration with partner regions. Third, the outward orientation of a smart specialisation process is also considered a field of action alongside clusters, social innovation, research infrastructure, etc. For example, internationalisation or outsourcing by technology companies must be an integral part of smart specialisation activities.

However, a review of RIS3 in the EU-13 suggests that internationalisation is not seen as crucial for the design and development of RIS3. In this paper, we explore the causes of this unsatisfactory situation and suggest ways forward. Our argument can be summarised as follows. Smart specialisation outward looking process is perceived primarily in terms of internationalisation of the design process, an international outlook in selection processes, and internationalisation developed as a separate area of activity (cf. internationalisation of technology companies). This is a view of internationalisation as a process of 'growing links between essentially discrete national economies or societies' (McGrew and Lewis 1992, p.5). As such, this view is at odds with the 
growing multiplicity of linkages and interconnections among regions, countries, firms and other organisations that characterise today's EU, including the EU-13, and the global economy. These linkages are at the level of very specific and narrow activities within business and R\&D processes, not at the level of complete global value chains. Thus, each of activities within the S3 areas has an external, or international or global dimension.

Innovation value chain activities include knowledge gathering, knowledge transformation and knowledge exploitation (Hansen and Birkinshaw 2007; Ropera and Arvanitis 2012). In this respect, internationalisation occurs in both upstream (R\&D) and downstream (GVCs, FDI) innovation activities. So, this aspect of S3 needs further development - especially in view of the need for complementarities and leverage between regional R\&D\&I activities and foreign knowledge, in both upstream (R\&D, R\&D alliances) and downstream activities (FDI, outsourcing, subcontracting). The issue is how can smart specialisation support the processes of international linkages, leverage and learning (Mathews 2002), focusing on internationalising individual implementation activities. We consider this issue to be of relevance not only for the EU-13 but for all emerging economies whose industrial and innovation policies have these objectives.

This paper is organised in five sections. 'Why Trans-Regional and Transnational Cooperation in Smart Specialisation? Key Issues for the EU-13' section discusses trans-regional and transnational collaboration in the context of the EU-13 and, in particular, how transnational collaboration is related to growth and technology upgrading in the EU-13. We discuss RIS3 in EU-13 countries and transnational activities including patents and participation in EU Framework Programmes 6 and 7 (FP6 and FP7). We also provide a discussion of the policy issues and investigate upstream and downstream collaborations, focusing our attention on the least developed aspect, i.e. downstream collaborations. 'Smart Specialisation and Technology Upgrading via and in Cooperation with Global Value Chains' section discusses how smart specialisation can help technology upgrading via GVCs and 'why' and 'how' regional smart specialisation activities are linked to global value chains. 'Strengthening Internationalisation of Smart Specialisation in the EU-13: Institutional Preconditions and Policy Environment' section addresses the key policy challenges and areas of policy action related to 'internationalising' smart specialisation including the institutional preconditions for this process to be effective. 'Conclusion' section summarises the major points and conclusions from this exercise.

\section{Why Trans-Regional and Transnational Cooperation in Smart Specialisation? Key Issues for the EU-13}

EU-13 countries are losing competitive advantage built strategically around cheap production factors and qualified workforce to other fast-growing big economies such as China, India or Brazil. EU-13 countries find themselves unable to compete internationally for FDI on terms of low-cost labour force, and thus, they are searching for new strategic approaches to ensure continued economic growth. One of the possible ways is through technological development, science-based innovation and capital involvement. This means in practice technological convergence, modernisation and upgrading as 
well as intensification of applied and technological research connected to business application. This is closely related to inter-sectoral and international cooperation as well as collaboration between scientific and business actors, and in consequence to smart specialisation.

Smart specialisation offers a unique opportunity for EU-13 countries to reinvent their R\&I strategies while building on their national/ regional assets, strengths and potentials. At the same time, EU-13 countries can improve international, inter-sectoral and private-public collaboration, as well as focus on niche activities to stimulate growth. By developing and implementing RIS3, ${ }^{1}$ EU-13 countries have opportunity to address challenges and bring expected growth in their regions.

\section{Research and Innovation Strategies in the EU-13}

Our analysis of RIS3 strategies in EU-13 showed that the transformative agendas prepared by regional and national governments are mostly inward looking and without strategic approach to trans-regional collaboration. Although the vast majority of EU-13 countries are open to internationalisation, mainly through FDI and MNEs, they do not consider trans-regional and transnational collaboration as potential vehicles of innovation and growth. Information provided in RIS3 strategies is rather limited and presented in a form of a brief summary of current transnational Science, Technology and Innovation (STI) activities among the home and mostly neighbouring countries. Reasons are manifolds, i.e. little interest in developing structured trans-regional collaboration, poor understanding of opportunities and management of trans-regional cooperation or insufficient capacity to explore, analyse and support trans-regional cooperation in smart specialisation.

On the other hand, the importance of GVCs for national economies in EU-13 is recognised by almost all EU-13 countries. Some EU-13 countries are aware that domestic businesses are insufficiently integrated in supplier chains of MNEs operating in the country. As we argue in the following section, innovation systems in EU-13 are de facto composed of two separate systems: FDI centred and domestic R\&D-based innovation systems focused around a handful of domestic new technology-based firms (Radosevic et al. 2010). FDI-oriented innovation systems are largely downstream or production oriented, while R\&D-based clusters of new technology-based firms are upstream-oriented providers of knowledge-intensive services for local firms. The patterns of technology upgrading of the EU-13 economies reflect this duality, which is also their key structural weakness.

\section{Dual Innovation Systems in the EU-13}

The EU-13 countries and regions have grown based on FDI, but investment has often been unrelated to domestic R\&D\&I capacities. This dualism between FDI and domestic innovation efforts has created a structurally weak innovation environment, which, despite improvements in productivity and $\mathrm{R} \& \mathrm{D}$, does not provide a basis for

\footnotetext{
${ }^{1}$ RIS3 are policy-integrated, place-based agendas that aim at transformation of European economies by exploitation of R\&I capacities and business potential while addressing global markets and European societal challenges.
} 
long-term growth. Upstream, R\&D systems in the EU-13 have become integrated into EU R\&D and Horizon 2020 networks, which gradually has led to improvements in research excellence, but not necessarily to improved local relevance (Radosevic and Yoruk 2014; Radosevic and Lepori 2009). Downstream, MNE subsidiaries have played an important role in integrating the EU-13 into international production networks. However, weak horizontal linkages between business sectors (foreign and domestic) and increasingly internationalised $\mathrm{R} \& \mathrm{D}$ are evidence of structurally weak innovation eco-systems. In this context, smart specialisation has emerged as a unique strategic opportunity to strengthen regional innovation systems in the EU-13 by coupling domestic innovation efforts with foreign R\&D\&I networks. Figure 1 depicts this situation and highlights the need for vertical levers on both the upstream and downstream sides, and missing horizontal levers or mechanisms that would link unconnected upstream and downstream parts of the innovation value chain.

Figure 1 suggests that there are de facto two innovation systems emerging in the EU-13 that have not been formally recognised. One system is focused on upstream R\&D activities and R\&D-based growth, exemplified by the group of new technology-based firms supporting the public R\&D system, providing knowledge-intensive business services (KIBS) such as software or niches of high-tech manufacturing in the EU-13 (Radosevic 2011). These activities have expanded based on support for Centres of Excellence and Centres of Competencies via the EU Structural Funds. The other innovation system is centred on FDI subsidiaries, which are plugged into MNE production networks. ${ }^{2}$ There is a variety of dyadic networks that are centred on MNE subsidiaries and linked to a limited, but gradually increasing number of local suppliers (McGowan et al. 2004; Radosevic and Sadowski 2004). There is some scant evidence suggesting that upgrading in these networks is still related largely to processes and that functional upgrading is limited (Pavlinek et al. 2010; Pavlinek and Zenka 2011), which does not promote technology upgrading by local suppliers and limits demand for local R\&D\&I.

The FDI system is more influential in terms of technology upgrading and employment and productivity effects. The R\&D-based system is narrow and organised around a limited number of domestic technology-intensive firms and public R\&D organisations and universities. Business R\&D is limited and concentrated in a few large firms, usually foreign-owned R\&D-based companies. With a few exceptions (Slovenia and the Czech Republic where business R\&D plays an important role), public R\&D is vital for fostering R\&D expenditure and scientific publication output.

The FDI and R\&D-based innovation systems also represent two areas of integration of the EU-13 in international R\&D\&I networks. Upstream, newly established national centres of excellence in the EU-13 are being plugged into the EU R\&D networks. This integration is leading to joint R\&D at the EU level and is reflected in the increased number of international co-inventions (joint patents) from the EU-13. Figure 2 compares the shares of co-inventions for the Central and Eastern European Countries (CEECs), the Brazil, Russia, India and China (BRIC), South EU countries (Spain, Greece, Portugal) and the EU-12 countries (other EU countries). It suggests that R\&D processes in the CEECs, measured by transnational patents, are highly integrated into international patent networks. Around $43 \%$ of CEECs patents are the result of a

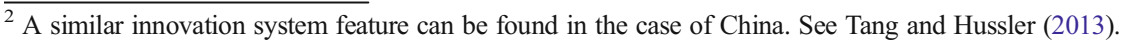



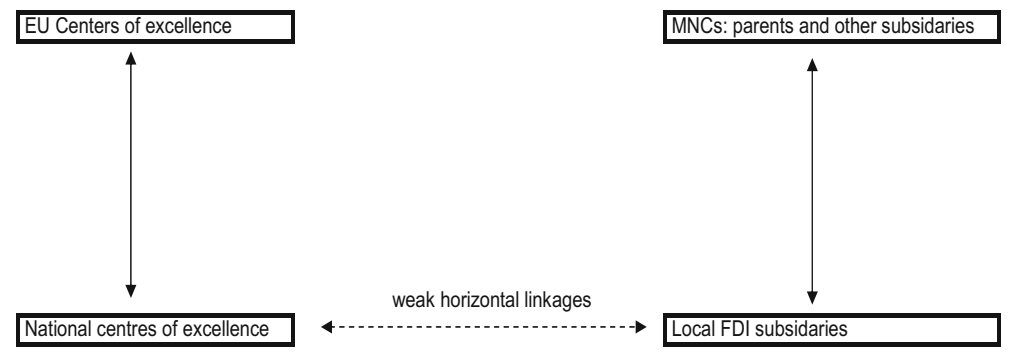

Source: authors

Fig. 1 Building vertical levers and missing horizontal levers to promote growth. Source: authors

co-invention process, an increase from almost zero registered 20 years ago. Also, there seems to be a convergence in the intensity of co-invention rates across the EU, with the EU-12 and the South EU countries achieving similar shares to the CEECs.

On the other hand, improvements in participation of EU-13 countries in Framework Programme 7 (FP7) compared to Framework Programme 6 (FP6) are rather modest. Specifically, the number of participations in FP7 (8.04 \%) was higher in absolute terms though not in relative terms with respect to FP6 (10.37\% of total). Participation rate thus decreased by $2.33 \%$ in FP7 compared to FP6. Similarly, total number of coordinations was higher in FP7 (1011) compared to FP6 (585), but proportionally, coordination registered a decrease by $1.77 \%$ (from 8.81 to $4.04 \%$ ). Also, change in EC contribution can be described as positive in terms of total EC contribution to EU-13 countries, but from total 14,445 million Euro allocated through FP6, EU-13 received $5.8 \%$ of total allocations that is proportionally more than EU-13 received from FP7 (4.25\%). On the contrary, EU-15 countries increased participation in FP7 compared to

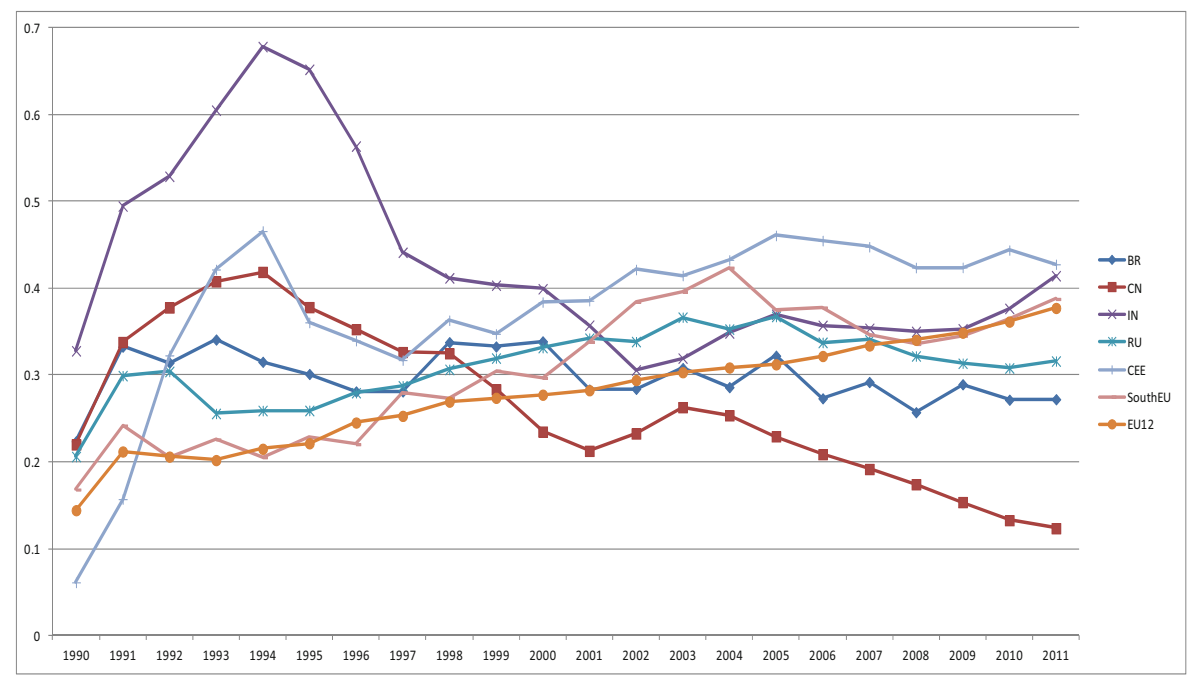

Fig. 2 Ratio of transnational patent applications with at least one national and at least one foreign inventor, to total number of transnational patents with national inventors. Transnational patent applications are those registered at the European Patent Office and through the Patent Cooperation Treaty. Source: OECD REGPAT. $B R$ Brazil; CN China; IN India; RU Russia; SouthEU Greece, Portugal and Spain; EU12 other EU countries; $C E E 11$ states from CEECs that joined the EU after 2004 
FP 6 by $2 \%$, but EC contribution decreased in relative terms by $1.68 \%$ and coordination rate by $2.54 \%$ (Table 1 ).

Figure 3 shows that Poland, the Czech Republic, Hungary and Slovenia are top FP 7 receivers. The same countries also improved best their performance in FP7 compared to FP6. Specifically, the increase in the EC contribution from FP6 to FP 7 in Poland was 222.97 million Euro, in the Czech Republic 155.35 million Euro, in Hungary 130.82 million Euro in Hungary and 94.42 million Euro in Slovenia. On the other hand, the countries that score best in terms of FP7 EC contribution per inhabitant are Cyprus (111.92 Euro per inhabitant), Slovenia (83.45 Euro per inhabitant), Estonia (66.17 Euro per inhabitant) and Malta (50.80 Euro per inhabitant).

In a nutshell, upstream R\&D collaboration and knowledge exchange of the EU13 are quite intensive. Radosevic and Ciampi Stancova (2015) list nine such currently established EU programs supporting inter-regional collaboration in R\&D\&I: European Territorial Cooperation, ${ }^{3}$ ERA-Nets, ${ }^{4}$ Joint Technology Initiatives, ${ }^{5}$ Knowledge and Innovation Communities, ${ }^{6}$ Joint Programming Initiatives, ${ }^{7}$ European Innovation Partnerships, ${ }^{8}$ ERA Chairs, ${ }^{9}$ Teaming for excellence and innovation, and Twinning for excellence and innovation.

In overall, there is a wide range of collaboration instruments available to the EU-13, focused on upstream areas with the aim of building excellence where currently it is lacking. On the downstream side, the EU level support mechanisms are much less present. The most recent instrument includes macro-regional strategies, such as the Baltic or Danube strategies, which seek to address common challenges in these countries with the aim of further enhancing economic development through innovation, territorial cooperation and cohesion. These strategies have no clear upstream/ downstream orientation; they are related to applied areas and require inter-regional collaboration.

The EU-13 countries have been successful in R\&D in relation to participation in the EU Framework Programmes, publications and patents (Radosevic and Yoruk 2014; Płoszaj and Olechnicka 2015; Jindra et al. 2015). However, this has not led to 'breakthrough innovations', or R\&D results having an impact on collaborations between the business sector and universities, new products and new services, or inclusion in GVCs. In other words, success in upstream areas (R\&D) has not been coupled with innovation in the business sector. To be precise, firms in the EU-13 have a similar share of turnover from innovation as a percentage of total turnover to EU-15 firms. However, their innovation activities are more related to the adoption and acquisition of imported machinery and equipment than R\&D and knowledge (Radosevic et al. 2015). As a result, innovation activities are fragmented, and/or weak horizontal links exist among the innovation eco-systems of the EU-13 (see Fig. 1).

\footnotetext{
$3 \mathrm{http} / /$ ec.europa.eu/regional_policy/index.cfm/en/policy/cooperation/european-territorial/

${ }^{4} \mathrm{http} / / / \mathrm{ec}$.europa.eu/research/era/era-net-in-horizon-2020_en.html

${ }^{5} \mathrm{http}: / /$ ec.europa.eu/research/jti/index en.cfm?pg=about

${ }^{6} \mathrm{http} / / /$ eit.europa.eu/activities/innovation-communities

${ }^{7} \mathrm{http}$ //ec.europa.eu/research/era/joint-programming-initiatives_en.html

${ }^{8} \mathrm{http} / / / \mathrm{ec}$. europa.eu/research/innovation-union/index_en.cfm?pg=eip

${ }^{9} \mathrm{http}: / /$ ec.europa.eu/research/era/era-chairs_en.html
} 
Table 1 Participation in Framework Programme 7

\begin{tabular}{|c|c|c|c|c|c|c|}
\hline \multirow[t]{2}{*}{ FP7 } & \multicolumn{2}{|l|}{ EC contribution } & \multicolumn{2}{|c|}{ Number of participations } & \multicolumn{2}{|c|}{ Number of coordinations } \\
\hline & $\begin{array}{l}\text { Contribution in } \\
\text { million euro }\end{array}$ & $\begin{array}{l}\text { Per cent } \\
\text { of total }\end{array}$ & Number & $\begin{array}{l}\text { Per cent } \\
\text { of total }\end{array}$ & Number & $\begin{array}{l}\text { Per cent } \\
\text { of total }\end{array}$ \\
\hline EU-13 & 1883.6 & 4.25 & 10,637 & 8.04 & 1011 & 4.04 \\
\hline EU-15 & 37,852 & 85 & 105,731 & 79.87 & 21,301 & 85.03 \\
\hline Associate countries & 3617.4 & 8.15 & 8697 & 6.57 & n.d. & n.d. \\
\hline Other countries & 1011 & 2.28 & 7317 & 5.53 & n.d. & NA \\
\hline Total & 44,364 & 100 & 132,382 & 100 & 25,052 & 89.07 \\
\hline
\end{tabular}

Source: authors. Based on European Commission database

\section{Integration Through Global Value Chains}

The optimal mix of local R\&D\&I efforts and acquisition of foreign knowledge via FDI and R\&D networks differs among regions, countries, activities and levels of innovation. Regions that operate close to the world technology frontier have a different balance between own R\&D and other activities in innovation GVCs and quite different internationalisation requirements. These regions are much stronger in upstream activities in the innovation value chain and have developed strategic partnerships in R\&D and production supply agreements in manufacturing. On the other hand, the EU-13 regions are integrated globally mainly through branch plants and have subcontracting relationships with regional GVCs although they are unable to generate a critical mass of local technological expertise that could be offered to global players. Thus, the internationalisation of regions, such as Baden Württemberg, a globally linked region at the technology frontier, is different from the internationalisation process in peripheral Romanian regions, which are outside global production networks.

Figure 4 depicts the share of foreign value in gross exports in selected OECD countries between 1995 and 2009. It provides a simple measure which shows how much value added is generated abroad for a given unit of exports and, thus, the degree

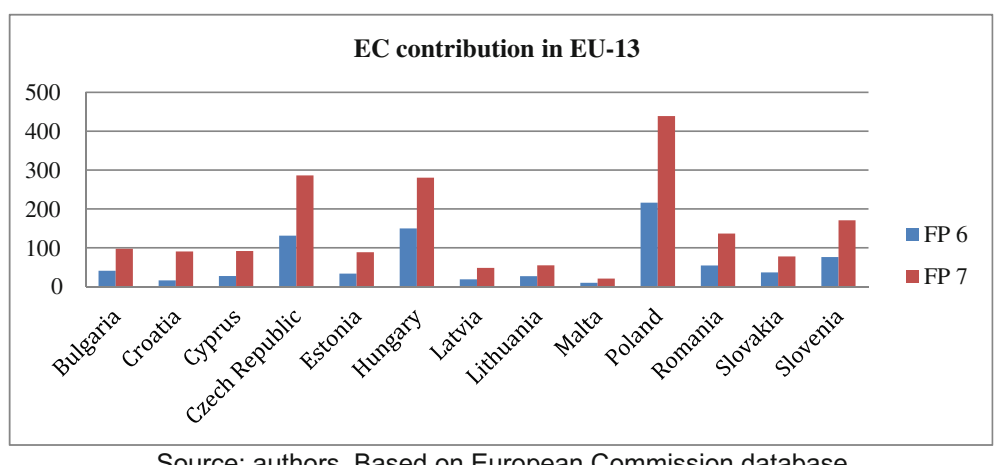

Source: authors. Based on European Commission database

Fig. 3 FP6 and FP7 EC contribution in EU-13 countries (million Euro). Source: authors. Based on European Commission database 


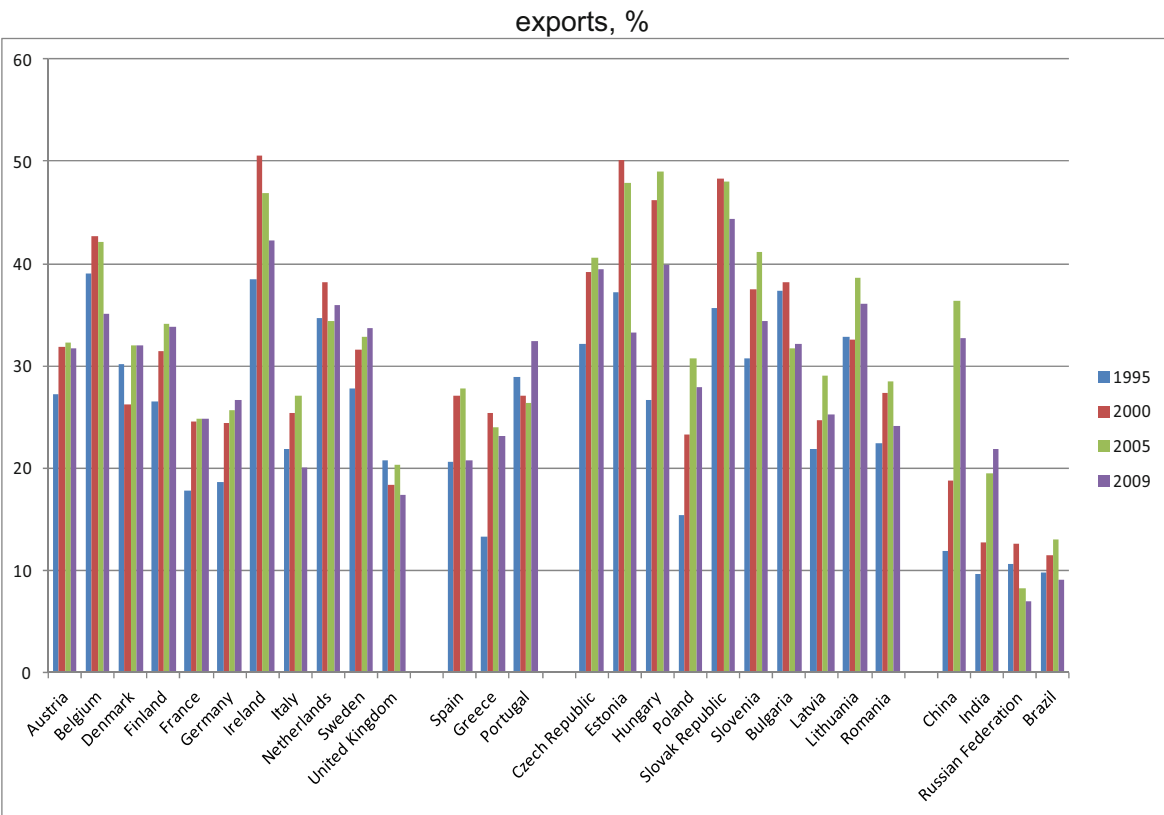

Source: Calculated based on OECD-WTO Trade in Value Added (TiVA) - May 2013. Data extracted on 11 Feb 2015 18:18 UTC (GMT) from OECD.Stat

Fig. 4 Foreign value-added export ratio - total foreign value-added share of gross exports, percent. Source: Calculated based on OECD-WTO Trade in Value Added (TiVA)-May 2013. Data extracted on 11 Feb 2015 18:18 UTC (GMT) from OECD.Stat

to which national economies are integrated in the global economy through production networks, i.e. through 'vertical specialisation'. The higher the ratio the higher is the foreign content and the higher the importance of imports compared to exports.

CEECs, which form the majority of the EU-13 group, have comparatively very high shares of foreign value added in their exports. These shares are partly influenced by their smaller size but are quite high compared to other EU countries of similar sizes. They all show sharply increasing shares of industrial integration from 1995, reversed only by the effects of the 2008 global financial crisis. The biggest increases in terms of vertical specialisation occurred in Hungary, Poland, Slovak Republic and the Czech Republic. Among the EU-13, especially central European countries, FDI and GVCs play major roles. The best known is the German-Central European supply chain cluster (GCESC) (see IMF 2013a, b) related largely to the automotive industry. The increase in foreign value added in four major countries in the GCESC (the Czech Republic, Slovak Republic, Poland and Hungary/CE4) appears to have led to an increase in domestic value added through productivity increases and created a demand for ancillary products and services in host economies. It seems that participation in the supply chain cluster has led to considerable technology transfer to the CE4 countries although there is no clear consensus on its magnitude due to high heterogeneity among firms in the fostering of skills.

Leitner and Stehrer (2014) show that the EU-13 benefits the most from stronger trade integration. They specialise in the low-value-added yielding assembly stage of the global production chain and do not gain from vertical specialisation. The EU-15 
countries are located higher up the value chain and tend to gain more in output, employment and labour productivity growth (gross output based) from more intense vertical specialisation. The growth of exports is advantageous for the EU-13 in terms of gross output and labour productivity, but on the flip side, higher degree of vertical specialisation does not necessarily translate into better industry performance. On balance, Leitner and Stehrer consider that the overall effect and losses in terms of value-added growth or labour productivity are compensated for by gains in terms of higher average export growth.

Overall, this suggests that the effect of vertical integration of the EU-13 is mixed as long as countries remain located in the low value-added assembly stages of the GVCs. This makes technology upgrading and innovation closely related to production capability in manufacturing and services, equally if not more important than a focus on upstream R\&D activities and programmes designed to generate new products and employment through a kind of 'trickle down' process from investment in R\&D excellence.

These two processes of integration - upstream R\&D and downstream FDI and GVCs - are often unrelated. They have led to numerous positive effects in terms of productivity and the contribution of FDI and improved scientific excellence but have left innovation systems in the EU-13 still structurally weak in terms of missing horizontal linkages between upstream and downstream R\&D\&I activities (see Fig. 5).

\section{Patterns of Technology Upgrading in the EU-13}

The lower part of Fig. 5 shows patterns of technology upgrading in the EU-13 (for a further elaboration see Radosevic et al. 2015). This pattern does not follow the linear innovation model logic depicted in the upper part of Fig. 5. This R\&D-based model of growth exists in enclaves in the EU-13, around a few clusters of new technology-based

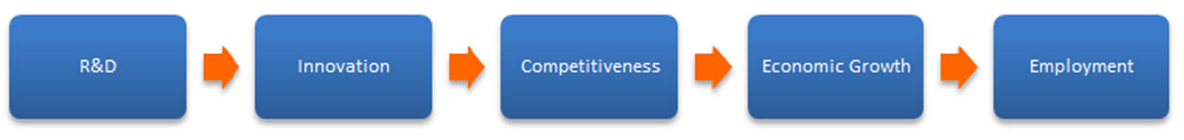

Model of technology upgrading in EU-13

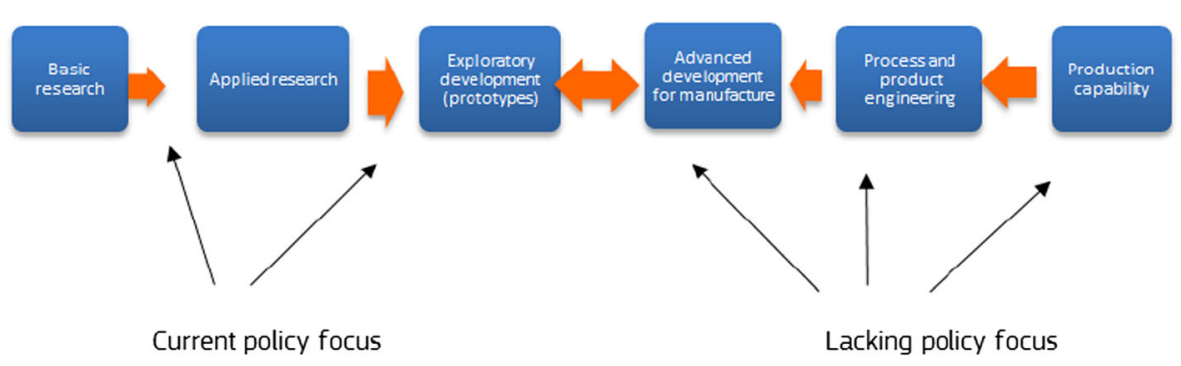

Source: Radosevic et al (2015)

Fig. 5 Alternative models of technology upgrading R\&D-based growth. From Radosevic et al. (2015) 
firms. However, it is of much lesser economic relevance compared to alternative patterns of technology upgrading (right hand-side of Fig. 5) around production capability and upgrading from production to technology capability.

This differentiation between two patterns of technology upgrading in the EU-13 is quite important since the current policy focus is on Horizon 2020, which is largely about R\&D-based growth. The policy model for the EU-13 should include the pattern of technology upgrading typical of catching-up economies. This model assumes that there is process of upgrading that starts with production capability improvements (quality) and is followed by process and product engineering improvements (incremental innovations). Following this, firms focus on mastering advanced manufacturing and exploratory developments (prototypes). The next step of applied research has a significant threshold and requires different types of skills and a well-qualified (PhD) labour force.

The key focus of the Horizon 2020 programme is R\&D-based growth, which is concerned mostly with advancement from applied research to development, i.e. how science-industry links and the knowledge triangle are used to commercialise the results of R\&D and make it relevant to the needs of the economy. On the other hand, innovation is prima facie a business activity and firms do not necessarily have to engage in $R \& D$ in order to innovate. More than half of the innovative firms in Europe do not perform in-house $\mathrm{R} \& \mathrm{D}$, and there is no difference in performance, measured by changes in turnover growth, between innovative firms that do and do not perform R\&D (Arundel and Kanerva 2010, p. 27). In the EU-13, the share of non-R\&D innovators is very high (Bulgaria $79 \%$, Romania $65 \%$, Latvia $59 \%$, the Czech Republic and Slovakia $55 \%$, Estonia $53 \%$, Lithuania $48 \%$ and Hungary $46 \%$ ). If we add firms that occasionally perform $\mathrm{R} \& \mathrm{D}$ or acquire extramural $\mathrm{R} \& \mathrm{D}$ from a parent firm or some other organisation, then the share of only R\&D innovators ranges between 5 and $30 \%$ (Arundel et al. 2008). Non-R\&D innovators focus more on process innovation and are less likely to draw on the expertise of design engineers (Arundel and Kanerva 2010). Thus, the key focus of the EU-13 in technology upgrading, at sector and firm levels, is about the shift from production to technology capability depicted in Fig. 5.

Patterns of current technology upgrading in the EU-13 show that entirely R\&D-led-based growth is a potentially important source of growth but that the main source of productivity is improved production capability (Kravtsova and Radosevic 2011). Innovative firms in the EU-13 are largely concerned with users and demand side factors, which are the major factors differentiating more and less successful innovations (see Radosevic and Yoruk 2011).

\section{Smart Specialisation in Support of Technology Upgrading Through Internationalisation: Assessment}

The Guidance for Expert Assessment of Regional Research and Innovation Strategies for Smart Specialisation (Foray et al. 2012, p.113) explicitly considers the integration of both upstream and downstream actions. However, assessment of downstream actions is restricted to 'downstream actions (which) aim to diffuse R\&I results from Horizon 2020 swiftly into the market' (ibid, p. 113). In terms of Fig. 5, the focus is mainly on the left hand-side, on technology upgrading at the expense of the right hand-side of enterprises as carriers of market-led innovation and productivity improvements. On 
balance, the international dimension is the least developed dimension in the S3 strategies and their implementation. Those EU-13 countries and regions, where foreign direct investors employ a substantial share of the labour force and are responsible for a major share of exports, have not often involved FDI actors directly in the S3 process.

This may reflect smart perception of smart specialisation as an opportunity to primarily strengthen local R\&D\&I capacities. Accordingly, it is necessary first to strengthen local R\&D\&I actors to enable them to link with FDI actors such as branch plants, R\&D centres, regional headquarters or contractors. Unfortunately, this overlooked the fact that FDI firms are the most productive among local firms, and some are important potential sources of knowledge exchange, subcontracting links and spillovers. However, most often, this reflected the weak capacity of public bodies to engage in a dialogue and consultation process with FDI actors.

To summarise, in this section, we have argued that

- $\quad$ R\&D in the EU-13 is collaborative in nature, while growth at firm level is closely related to export, FDI and vertical specialisation.

- Both the upstream and downstream parts of innovation process (both R\&D and non-R\&D) are strongly internationalised but weakly linked.

- Smart specialisation design emphasised internationalisation as an important activity but stressed upstream or R\&D activities related to Horizon 2020 more than downstream activities related to GVCs. However, during the RIS3 implementation phase, attention should be paid to both synergies and integration/upgrading in GVCs.

- A particularity of the EU-13 economies is that much of their innovation activities are non-R\&D and at the core of their technology upgrading is the transition from production to technology capability.

- Internationalisation of upstream (R\&D) activities in the EU-13 is more advanced than the internationalisation of downstream and non-R\&D activities.

Against this background, in the next section, we focus on the issue of internationalisation through GVCs and how they can be supported and made integral to smart specialisation. This discussion is at a lower empirical level of detail than is desirable for several reasons. First, there has been no systematic mapping of collaborative networks; the data are fragmented and/or not available for confidentiality reasons. Second, the literature on trans-regional cooperation in the context of smart specialisation and the role of regional governments/authorities in the EU-13 is limited. Work exists on the globalisation of regions but is confined largely to metropolises and metropolitan rankings.

\section{Smart Specialisation and Technology Upgrading via and in Cooperation with Global Value Chains}

Internationalisation and innovation are inextricably linked (Altomonte et al. 2013). There is a positive and strong correlation between the extent of involvement of firms in both international and innovation activities (ibid). This is quite important for regional R\&D\&I policy which overlooks this new stylised fact of international economics. In 
addition, innovation systems are becoming internationalised although the institutions that support them have remained country-specific (Carlsson 2006; Gosens et al. 2015). The interaction between national and foreign and, increasingly, global innovation systems takes place within increasingly globalised networks of suppliers rather than single firms. As GVCs become more fragmented, MNEs can be considered 'international coordinators', whose main competence is to organise effectively the flows of value-added activities distributed among individual subsidiaries (Rugman et al. 2011).

MNEs and GVCs have been and continue to be an important mechanism for EU-13 firms to learn and innovate. Participation in GVCs is a crucial means for obtaining information on the type and quality of products and technologies required by global markets and of gaining access to those markets (Pietrobelli and Rabellotti 2011). However, this by itself is not sufficient for technology upgrading. Yoruk (2012), in the first in-depth study of technology upgrading through GVCs in the EU-13, shows the major importance of both knowledge and production networks for firm upgrading. Yoruk (2012) argues that by narrowing the learning opportunities for upgrading to interactions with global buyers within GVCs, as if they were the sole source of knowledge, is extremely misleading. She shows the major importance of local and national networks (not only GVCs) for firms' technology upgrading. Also, opportunities offered by GVCs are of little use unless firms have the ability to internalise this external knowledge based on their human resources, and internal training and research.

Thus, GVCs and MNEs are no panacea, but equally, it would be misleading to presume that reliance on only own forces would ensure technology upgrading. GVC suppliers and local MNE subsidiaries are at the intersection of two flows of knowledge - global and national or local — which can facilitate learning from MNEs and linking with external sources of expertise and know how, and use them to leverage local capabilities (Mathews 2002). Since regional sources of knowledge are not enough, it is important to create the mechanisms to enable involvement in the international knowledge creation and diffusion process. The empirical evidence suggests that there is a variety of roles that MNE subsidiaries can play in relation to regional or national knowledge systems (Marin and Arza 2009). They can be highly innovative or evolve towards more sophisticated technological activities, or they can remain isolated and not innovative. The subsidiaries that have managed to move to intensive innovative activities are those that have drawn heavily on learning links with their parent companies, i.e. they are integrated or connected to international networks and are entrepreneurial. The more connected subsidiaries are to the global production network, the greater their involvement in innovation locally (Marin and Arza 2009).

\section{How Smart Specialisation Can Help Technology Upgrading Through and in Cooperation with GVCs}

From a smart specialisation perspective, there are three important aspects to consider in relation to GVCs. First, the choice of $G V C$ is suited to regional R\&D\&I and manufacturing or services capacities, second, how firms can be assisted to 'climb the ladder' or move from process, to product, to functional or value chain upgrading, and third, discovery of 'new ladders' or new production 
and market uses for existing capabilities, not originally envisaged by either the foreign or local partners. ${ }^{10}$

\section{Matching regions with value chains}

Smart specialisation is an opportunity to target investors (by FDI promotion agencies) with the aim to leverage the effect of the smart specialisation strategy on regions. Also, regions' smart specialisation strategy should be used as the basis for better FDI promotion activities to strengthen regional development (Ecorys 2013).

From a smart specialisation perspective, search activities are focused on identifying not only emerging/promising markets but also promising or appropriate value chain leaders. The idea is that a good match between the type of region and the type of GVC can have catalysing effects on the region in terms of technology spillovers. Table 2 presents the relationship between types of regions in the EU-13 and the modes of their integration into GVC/MNE networks. X indicates strength or suitability of a specific activity for a specific type of the region with $\mathrm{XXX}$ being the strongest and $\mathrm{X}$ the weakest.

'Globally connected' regions are usually metropolitan or capital regions with extensive participation in national and international competitive research programmes and international technology networks. 'Cluster building' regions are those that have a critical, or subcritical, but potentially critical, mass of firms in the respective technology areas. Many of these are manufacturing regions with relatively high knowledge absorptive capacity.

'Deepening pipelines' regions partly overlap with the cluster building regions in terms of links to GVCs, but they do not have a critical mass of the local clustering firms and have local infrastructure deficiencies which significantly weaken their absorptive capacity. 'Peripheral regions' are marginalised regions, which may be rural areas in less developed EU-13 countries or old industrial centres that have not been restructured but which effectively are excluded from the internationalisation process in relation to FDI and GVCs. The activities described in Table 2 are necessarily generic or indicative, and need to be specified in terms of technology and sector or area of application. However, they indicate the match or mismatch between what is possible and what is desirable in terms of regional infrastructure and capacities, and type of activities that could be attracted via the GVCs. Attracting non-production activities, such as research, marketing and distribution, for a region that does not have the required infrastructure and skills for upstream GVC activities, may not be beneficial in relation to the region's potential comparative advantage regardless of the available funds and vision for the future. Equally, specialising in activities in which the region already has strengths is merely pandering to existing comparative advantage, which may not persist and may not lead to further diversification.

From the perspective of GVCs, globalised regions have strong advantages in the non-production stages of the innovation chain. They assume a gateway role for MNEs by housing their regional or their national headquarters (Fratesi 2012). Regions with few local clusters are the best placed to become integrated into global production

\footnotetext{
${ }^{10}$ We use the word 'ladder' to emphasize that GVCs are potential levers of regional economic growth and technology upgrading.
} 
Table 2 Types of regions in EU-13 and types of internationalised business activity

\begin{tabular}{|c|c|c|c|c|}
\hline $\begin{array}{l}\text { Type of } \\
\text { business } \\
\text { activities/type } \\
\text { of region }\end{array}$ & $\begin{array}{l}\text { 'Connecting } \\
\text { globally' }\end{array}$ & $\begin{array}{l}\text { 'Cluster } \\
\text { building' }\end{array}$ & $\begin{array}{l}\text { 'Deepening } \\
\text { pipelines' }\end{array}$ & $\begin{array}{l}\text { 'Peripheral } \\
\text { regions' }\end{array}$ \\
\hline & $\begin{array}{l}\text { Capital regions } \\
\text { building R\&D } \\
\text { strengths and } \\
\text { international } \\
\text { connections }\end{array}$ & $\begin{array}{l}\text { Small grouping } \\
\text { of potentially } \\
\text { competitive } \\
\text { business with } \\
\text { limited local } \\
\text { connectivity }\end{array}$ & $\begin{array}{l}\text { Region dependent on } \\
\text { limited number of } \\
\text { global production } \\
\text { networks/global } \\
\text { value chains }\end{array}$ & $\begin{array}{l}\text { Regions outside of } \\
\text { access to global } \\
\text { production } \\
\text { network }\end{array}$ \\
\hline Research & XXX & & & \\
\hline Innovation & XXX & $\mathrm{XX}$ & & \\
\hline Production & $\mathrm{X}$ & $\mathrm{XXX}$ & $\mathrm{XX}$ & $\mathrm{X}$ \\
\hline $\begin{array}{l}\text { Marketing } \\
\text { (sales) }\end{array}$ & XXX & & & \\
\hline Distribution & XXX & $\mathrm{XX}$ & & \\
\hline $\begin{array}{l}\text { Administrative } \\
\text { support } \\
\text { (regional } \\
\text { headquarters) }\end{array}$ & XXX & & & \\
\hline
\end{tabular}

Source: authors. Taxonomy of regions is modified and adapted based on Benneworth and Dassen (2011)

networks and the stages of production such as innovation and distribution. They lack connectivity and knowledge-intensive business services firms (Capello and Perucca 2013). They may be located close to the country or regional capital that engages in these non-production functions. Deepening pipelines regions and especially peripheral regions are well placed to attract branch plants. The objective may be functional upgrading but largely within the production mandate.

The key to internationalisation via smart specialisation is to fit the type of region to the respective activity and, thus, the type of GVC. This taxonomy represents an ad hoc framing of a problem that requires in-depth analysis of each region from a GVC perspective in order to make it applicable. As part of smart specialisation activities, it is important to embark on an analytical process to identify which type of GVC will best fit regional capacities. Local firms will be required to satisfy the product quality, delivery time, process efficiency, environmental, labour and social standards requirements of these chains. However, these requirements are neither generic nor easily recognisable, and differ across industries and technologies. Sectoral specificities matter and influence the mode and extent of upgrading in clusters integrated in GVC (Giuliani et al. 2005). In 'buyer-led' GVCs, which are usually hierarchical, product and process upgrading are enhanced, but functional upgrading is almost always inhibited ${ }^{11,12}$ (Giuliani et al. 2005). If confined to individual firms, these upgrading strategies are

\footnotetext{
${ }_{11}^{11}$ Buyer led value chains are usually organized by large distributors or global retailers.

${ }^{12}$ Process upgrading comprises more efficient transformation of inputs into outputs through a reorganization of the production system or introduction of superior technology. Product upgrading involves moving into more sophisticated product lines in terms of increased unit value. Functional upgrading involves the acquisition of new, superior functions in the chain, such as design or marketing, or abandoning existing lower-value-added functions to focus on higher-value-added activities. Inter-chain upgrading refers to applying the competence acquired in a particular function to move into a new chain.
} 
rarely supportable. Hence, it is important to try to create a critical mass of local suppliers that will generate demand for supporting services. Within that context, a smart specialisation process might 'discover' areas where a critical mass of local demand for such 'upgrading services' could be created. For example, this applies to industry-specific programmes of quality improvement services or to programmes to meet international industry standards or to supply technology-specific training. It would be preferable if these were designed and implemented in collaboration with the users of these services, including GVC leaders.

The more developed the local support, the more numerous will be the opportunities to get involved in higher value-added activities. So, strategic analysis for the EU-13 should identify the needs in the system of organisations that provide technology diffusion and extension services, such as Metrology, Standards, Testing and Quality (MSTQ), and technical and organisational consultancies (or knowledge-intensive business services), and later, R\&D\&I support (Pietrobelli and Rabellotti 2011). However, these aspects cannot be unrelated to potential GVCs, which may be likely candidates for location or expansion in the region. In this case, stakeholder involvement in the process of smart specialisation can avoid irrelevant or overly generic R\&D\&I infrastructure services, and identify those for which there is effective demand from local firms.

\section{Smart specialisation - a process for 'discovering' new GVC-related opportunities} or 'climbing the ladder'

Choosing the right GVC and creating the appropriate 'milieu' to embed it into the regional economy are the first, although static dimensions of the selection process. There is also a dynamic dimension, consisting of discovering new opportunities for further technology upgrading within the GVC. The types of capabilities and external support required for each type of upgrading differ for different types of global value chains or MNE subsidiaries. These are presented in Table 3 as ranging from arm's length market relationships to major types of value chain relationships and two forms of vertical integration via MNEs. The major types of global value chains are described below (based on Gereffi and Fernandez-Stark 2011, pp. 9-10).

- Market: Market relationships with the GVC are relatively simple since they are based on product specifications that are easily transmitted and suppliers can produce their goods with minimal input from buyers. These arms-length exchanges require little or no formal cooperation among the actors, and the cost of switching to new partners is low for both producers and buyers.

- Modular: In modular relationships, suppliers make products to customers' specifications and take full responsibility for process technology, using generic machinery that spreads their investment across a wide customer base. Linkages (or relationships) are more substantial than in simple markets because of the amount of information flowing across the inter-firm links.

- Captive: In captive chains, small suppliers are dependent on one or a few buyers which often wield huge power. The core competence of the lead firms tends to be in areas outside of production, helping suppliers to upgrade their production 
Table 3 Types of GVCs and the internationalisation of the smart specialisation

\begin{tabular}{|c|c|c|c|}
\hline $\begin{array}{l}\text { Type of value } \\
\text { chain/MNE subsidiary }\end{array}$ & $\begin{array}{l}\text { Strategic aim of } \\
\text { internationalisation of } \\
\text { smart specialisation }\end{array}$ & $\begin{array}{l}\text { Role of } \\
\text { GVC leader/MNE }\end{array}$ & $\begin{array}{l}\text { Role of regional } \\
\text { public support }\end{array}$ \\
\hline $\begin{array}{l}\text { Arm's length } \\
\text { relationships }\end{array}$ & $\begin{array}{l}\text { Building competencies for } \\
\text { entry into GVC }\end{array}$ & $\mathrm{n} / \mathrm{a}$ & $\begin{array}{l}\text { Technical support } \\
\text { services for meeting } \\
\text { GVCs standards }\end{array}$ \\
\hline Modular chains & Learn how to meet GVC standards & Passive & $\begin{array}{l}\text { Technical support } \\
\text { services for } \\
\text { meeting GVCs standards }\end{array}$ \\
\hline Captive chains & $\begin{array}{l}\text { Support upgrading of local } \\
\text { suppliers up to a level of } \\
\text { competent supplier }\end{array}$ & Active & $\begin{array}{l}\text { Support to process and } \\
\text { product upgrading }\end{array}$ \\
\hline Relational chains & $\begin{array}{l}\text { Strengthen production and } \\
\text { linkages capabilities }\end{array}$ & Cooperative & $\begin{array}{l}\text { Support to product } \\
\text { upgrading }\end{array}$ \\
\hline $\begin{array}{l}\text { Highly integrated } \\
\text { subsidiaries }\end{array}$ & $\begin{array}{l}\text { Assist subsidiaries to operate as } \\
\text { conduit between local and } \\
\text { MNE innovation system }\end{array}$ & Active & $\begin{array}{l}\text { Support to product and } \\
\text { functional upgrading }\end{array}$ \\
\hline Isolated subsidiaries & $\begin{array}{l}\text { Assist subsidiary to become } \\
\text { highly integrated subsidiary }\end{array}$ & Passive & $\begin{array}{l}\text { Support to improve } \\
\text { linkage capabilities }\end{array}$ \\
\hline
\end{tabular}

Source: adapted based on Gereffi and Fernandez-Stark (2011), Pietrobelli and Rabellotti (2011), and OECD (2013)

capabilities that do not encroach on this core competency and benefit the lead firm by increasing the efficiency of its supply chain.

- Relational: Relational global value chains require frequent interactions and knowledge sharing between the parties. Lead firms specify what is needed and, thus, have the ability to exert some level of control over suppliers.

MNE subsidiaries are heterogeneous in terms of their internal capabilities and their role within the MNE and the regional economy. Highly integrated subsidiaries are those that are embedded in both the MNE innovation process and the regional knowledge network. Research shows that this type of subsidiary is a real conduit of knowledge transfer and the source of technology spillovers for the regional economy (Marin and Sasidharan 2010; Cantwell and Ram 2005; Marin and Giuliani 2011). In contrast, from a regional economy perspective, isolated subsidiaries do not operate as a source of technology spillovers. They are not embedded in MNEs' innovation processes and are isolated from local knowledge networks although they may have superior equipment and technology. In isolated subsidiaries, joint projects with local suppliers do not go beyond commodity supply. They can be entirely dependent on or isolated from flows of knowledge from the MNE, but in either case, they are not engaged in knowledge exchange within the region (Marin and Giuliani 2011).

Arm's length relationships in GVCs, modular chains and captive chains are either solely or largely about process upgrading. In each case, the aims of smart specialisation strategies are quite different depending on the type of GVC based on differences in the required capabilities. Product upgrading is possible within captive and relational chains, although lead firms retain tight control. Value chain relationships are usually confined to production or services and do not involve the full range of the firm's non-production 
activities such as $R \& D$, design or marketing. Thus, functional upgrading is limited to the production process.

The role of external support for firms' upgrading varies with the nature of the required capabilities. In the case of process upgrading, this is related mostly to quality and compliance with specific industry and technology standards. The role of the GGVC leader or MNE varies across different types of relationships from passive, to cooperative, to active. Similarly, the role of regional public support varies depending on the required capabilities and firms' technology upgrading strategies.

Functional diversification can be considered a type of technology upgrading since it involves the uptake of relatively more sophisticated, knowledge-intensive and higher value adding assignments that complement the production-related tasks (Szalavetz 2012 , p. 316). Functional upgrading to non-production services requires knowledge-intensive services and business services, which in the EU-13 (with exception of a few capital regions) are not competitive, which limits the potential for service innovation to support economic restructuring. However, these activities are important to increase the value added generated by the manufacturing sector (Komninos et al. 2014).

The major structural shift among EU-13 firms consisted of the transition from only production or only assembly activities to Original Design Manufacturer (ODM) and then Own Brand Manufacturer (OBM). GVCs are an effective mechanism for upgrading at least up to ODM level, and there is evidence that they do not hinder functional upgrading (Yoruk 2012). Advancement beyond these levels is not easy but may be enabled by licensing, franchising or alliances, or collaboration for marketing with a (foreign) consulting firm.

The more autonomous the firm, the more it will be able to engage in functional upgrading or development of a larger number of functions. However, such upgrading implies increased fixed costs to establish additional functions (strategy, R\&D, marketing, etc.) not necessarily accompanied by increased production volumes or increased profitability. As a result of this trade off, Rozeik (2011) shows that the pattern of company upgrading in the Central European automotive industry is more scale based (i. e. involves a large increase in production volume) as opposed to scope based or functional upgrading.

In the case of local subsidiaries of MNEs, product and functional upgrading requires changes to the subsidiary's mandate. Although there are examples of success in the EU-13, such as Siemens which diversified into higher value-added activities, the share of upgraded subsidiaries in this group is small. Szalavetz and Sass (2011) point to the unfounded assumption that much depends on the subsidiary's efforts and especially its entrepreneurship. Research on FDI subsidiaries in four CEE countries shows that subsidiaries have relatively strong autonomy in business functions but within a predominantly production-oriented mandate (Majcen et al. 2009). In production-oriented mandates, quality seems to be paramount, and high productivity growth is ensured if the subsidiary is left alone. Subsidiaries control 'how' things will be done but have significantly less control over strategic issues such as which line of businesses should be pursued. However, if policy is aimed towards functional upgrading, leaving the subsidiary to its own devices would seem to make this unlikely.

From a smart specialisation perspective, how to motivate MNE headquarters or GVC leaders to refine the mandates of entrepreneurial subsidiaries is a key issue. The importance of this is obvious in the case of isolated subsidiaries compared to 
subsidiaries that are well integrated into both MNE networks and regional knowledge networks. Assessment of new opportunities is cognitively biased not only by the intra-MNE perspective of the headquarters but also by lack of knowledge about local opportunities. The benefit to be derived from MNEs' extending subsidiary mandates beyond the original market or resource seeking investment and is not obvious unless there are significant infrastructural improvements in the regional technical and knowledge infrastructures. Such improvements must be coordinated to ensure that they are technology or firm specific.

\section{Smart specialisation — the process of 'discovering a new ladder'}

In addition to functional upgrading, MNE subsidiaries can discover opportunities being offered 'on the side', in the value chain stage in which the firm is currently engaged (Pietrobelli and Rabellotti 2011). This process is not necessarily confined to the GVC lead firm and a local supplier, and usually is shaped by the infrastructural support for R\&D\&I on which the firm can rely. Areas of new opportunities emerge or are 'discovered' through close interaction among domestic firms, GVC lead firms, and local universities or public research organisations. This is closest to the original idea of smart specialisation but is confined here to a 'discovery process' involving the GVC coordinator, local suppliers and the local R\&D infrastructure.

The more sophisticated the technology requirements of GVCs and MNEs, the greater the requirement for regional support systems to support the building of capabilities for technology upgrading within GVC and MNE networks. In terms of smart specialisation activities, this does not require a separate system of support, but rather a reorientation of the existing networks towards the needs of these firms. However, a major change is required in the way that regional authorities and supporting organisations cooperate with GVC leaders, in understanding the key capabilities deficits among local firms, and the infrastructural requirements for the next stage of their technology upgrading.

The overall aim of internationalised smart specialisation is to extend participation in supply chains from commoditised and shallow, to deep and integral participation. This is important since not all GVC activities involve technology upgrading which could ensure sustainable competitive advantage and growth (Steinfeld 2004). Not even functional upgrading necessarily leads to greater value capture (Szalavetz 2012). However, the scope for technology upgrading through and in cooperation with GVC leaders is an inevitable step on the path to technology upgrading among the EU-13. This includes intra-chain upgrading as well as inclusion in new GVCs.

Internationalised smart specialisation is about discovering new ways of partnering which go beyond passive acceptance of the rules governing connectivity upstream and downstream. They are also about discovering new opportunities for more integral processes and opportunities that must be coordinated and co-designed with upstream and downstream partners in the network. If the gaps are not too large, the smart specialisation discovery process might allow local firms to organise collective action towards full functional upgrading, by moving to non-production parts of the value chain, e.g. by building a regional or national brand. Finally, if smart specialisation is about specific activities or technologies that can be used in multiple supply chains, e.g. producing a standalone component that can be plugged into a variety of downstream 
products, this could lead to entirely new innovation strategies that go well beyond GVC dependence.

\section{Identifying Internationalisation Opportunities Through Smart Specialisation: at Which Level?}

The level at which smart specialisation priorities are identified and supported lies between micro-project and sector-level policies. If the level of granularity is too fine, the outcome will be micro-projects, if too coarse the result will be sectoral policy. From an internationalisation perspective, it would seem logical to focus on the quality or value added of different business functions (manufacturing, development, engineering, logistics, etc.). However, this overlooks the possibility that subsidiaries or GVC suppliers might be involved in high value-added activities in one part of the business function while at the same time being simple implementers in another part of the same business function (Szalavetz 2012; Rugman et al. 2011). This would suggest that policy should not identify a subsidiary or GVC supplier that has one dominant function and a presumed value-added level. A specific dominant function in reality might consist of a mix of diverse value adding activities, whose expected level of value added might be marginal or non-existent. This would suggest that policy should be targeted towards activities rather than whole functions, whose description should be sufficiently specific to reveal their technology, knowledge or value-added content. In other words, the function should be an activity whose description is sufficiently specific to identify its technology and knowledge complexity level. The challenge for smart specialisation analysis is how to survey demand and supply of technology activities at this level to reveal potential areas for technology upgrading activities.

\section{Strengthening Internationalisation of Smart Specialisation in the EU-13: Institutional Preconditions and Policy Environment}

The inter-regional and transnational dimensions must be an integral part of any smart specialisation programme. Thus, we do not envisage adding more steps to those stipulated in Annex I of the Guide for RIS3, which include the following:

Step 1. Analysis of the regional context and potential for innovation

Step 2. Governance: Ensuring participation and ownership

Step 3. Elaboration of an overall vision for the future of the region

Step 4. Identification of priorities

Step 5. Definition of coherent policy mix, roadmaps and action plan

Step 6. Integration of monitoring and evaluation mechanisms

However, we need to pay particular attention to steps 1, 2, 4 and 5. As part of step 1, we need to review the existing degree of internationalisation in the region, i.e. scale, scope and types of integration into GVC and MNE networks through local subsidiaries and subsidiaries' links with local suppliers and public infrastructure organisations.

The process of discovering new internationalisation opportunities is similar to the smart specialisation process of entrepreneurial discovery (steps 1-4), but with three 
possible directions. First, it is necessary to choose and attract new GVCs or MNEs to matching regions as discussed in 'Matching regions with value chains' section. Second, it is necessary to identify technology upgrading opportunities among existing local suppliers and local subsidiaries. This is the process of discovering new GVC-related opportunities or 'climbing the ladder' ('Smart specialisation - a process for 'discovering' new GVC-related opportunities or 'climbing the ladder"). Third, there is the process of discovering new opportunities alongside existing GVCs or discovering new GVC-related opportunities, i.e. 'a new ladder' ('Smart specialisation - the process of "discovering a new ladder").

The choice among these options depends on the level and competencies of local suppliers and the regional supporting technical infrastructure. However, unlike the process of 'inward' oriented smart specialisation or specialisation where local public and private actors act autonomously based on their knowledge of the external environment; in this process, the actors are not fully autonomous. Local subsidiaries of MNEs have very different degrees of strategic autonomy and find themselves with quite different degrees of freedom in relation to the strategies they can pursue. GVC leaders' views about the role of local suppliers may be different to the views of these local suppliers. This makes the process of 'entrepreneurial discovery' more complex since stakeholders' opinions about the situation and the regional strengths and opportunities will differ from those held by international actors. These cognitive biases are to be expected, and they should be reconciled through a process of 'entrepreneurial discovery'.

However, given the higher barriers to the process of 'entrepreneurial discovery' that involves foreign actors, two factors involved in this process deserve special attention. These are the institutional preconditions for smart specialisation (step 2) and policy environment (step 5). The institutional capacity for smart specialisation is implicitly considered to be unproblematic although, in reality, it is a major area of concern. Experience shows that it is a major stumbling block to effective implementation of smart specialisation, especially in the EU-13. The internationalisation of smart specialisation adds further complexity since the EU-13 regions usually do not have developed mechanisms for interaction with foreign investors after completion of a capital expenditure project. 'Investor aftercare' (with the exception of CzechInvest) ${ }^{13}$ remains rare. It involves activities to support expansion, reinvestment and the development of R\&D activities, searching for suppliers in the region, providing support for training and recruitment, promoting cooperation with vocational colleges and universities, etc. Another precondition is a developed policy environment oriented to linking and leveraging domestic and foreign investors and suppliers both upstream (R\&D, technical services) and downstream (manufacturing and services). Smart specialisation on its own will not be enough to overcome the barriers to actors' engagement in 'discovery processes'. Strong incentives and appropriate policy instruments will be needed to shift expectations in the direction of long-term R\&D\&I-oriented activities.

\footnotetext{
${ }^{13}$ CzechInvest is the Czech Investment and Business Development Agency. See http://www.czechinvest.org/en.
} 


\section{Institutional Pre-conditions for Internationalising Smart Specialisation}

The institutional preconditions for smart specialisation, such as the administrative requirements and policy capacity, are new for the EU-13 (see Karo and Kattel 2015). Internationalisation of smart specialisation inevitably exacerbates these weaknesses since the EU-13 regions have no mechanisms in place enabling continuous interaction with foreign owned firms. In relation to this very important dimension of the smart specialisation process, we highlight a few priority areas and issues:

- Public-private coordination mechanisms, including meso-level coordination mechanisms (activities, sectors and GVCs), need to be developed further.

- The vertical-horizontal nature of smart specialisation policies and accompanying administrative and policy preconditions needs further investigation.

- Sector and technology-specific expertise is required to evaluate smart specialisation alternatives.

- Tailor-made policies and greater policy capacity are needed.

- The 'entrepreneurial discovery process' requires further investigation including consultation with public sector stakeholders.

- The institutional conditions and requirements for experimentation within an annual multi-year programming framework need to be defined.

However, the above requirements must be based on an organisation with the ability to assume responsibility for FDI/GVCs and innovation. FDI is usually managed by an FDI promotion agency, and R\&D\&I are usually overseen by the Ministry for Science and Technology. However, these arrangements vary across the EU-13. ${ }^{14}$ It seems that what matters is not the specific organisational form, which can vary from country to country, but the success or failure of the organisation. This calls for a better understanding of specificities of each country and of the organisational and policy factors in the EU-13 that lead to organisational success in public policy.

The EU-13 has seen a proliferation of agents detached from ministries and with different levels of policy autonomy. It is hoped that this will ensure the quality of public policy implementation including interaction with foreign firms. This process of 'agencification' has taken place as part of the EU accession process. In the pre-accession period, candidate countries saw policy transfer as necessary to secure EU membership rather than considering it a tool for improving the quality of policy design and implementation at the domestic level (Nakrosis 2015, p. 135). As a result, the EU-13 countries all have FDI agencies. These actors are potentially important players in the implementation of smart specialisation and its integration and embedding in local economies and innovation systems. However, the reality is diverse roles of investment promotion agencies. Cass (2007) distinguishes among their 'symbolic', 'practical', 'comprehensive' and 'strategic' roles. Symbolic agencies are legal organisations with varying facilities, which exist, but do not act. 'Practical' actors are those that provide a substantial range of information and services to new and existing

\footnotetext{
${ }^{14}$ For example, in the Czech Republic, the entity responsible for the modernization and integration of the food sector into the EU industrial networks is the industry association. CzechInvest has managed successfully to integrate management of the EU Structural Funds with FDI and innovation programmes.
} 
investors. Comprehensive' agencies try to promote the relevant country to potential investors and provide certain services, with varying degrees of success. Most agencies belong to this category. Strategic investment promotion agencies are clear about the areas where FDI is needed and have the influence and capabilities to be successful. According to Cass (2007, p. 103) 'among transition countries CzechInvest is perhaps the only one that comes into this category'.

Thus, strategic investment promotion agencies are a vital missing precondition for the promotion of technology upgrading via FDI and GVCs. Their absence is due to the high rates of politicisation of agencies in the EU-13, the frequent changes of governments which hinder organisational learning, a strong legalistic approach to the design of public sector organisations which focuses on formal and structural features at the expense of operational characteristics and relationships within the environment (Randma-Liiv et al. 2011, p. 162).

However, as already mentioned, the precise form of agency or body responsible for implementing the internationalisation of smart specialisation is secondary to whether this organisation is a case of organisational success or organisational failure. There are several features that explain CzechInvest's success as a strategic investment promotion agency including the following (Benáček 2009, 2010):

- Adoption of high standards for management and managerial techniques based on teamwork, managerial initiative and regular monitoring of performance

- Political consensus at the national level that the agency should be independent and protected from 'political bickering'

- Freedom to act like a private consultant whose services are free of charge

- Provision of support programmes to upgrade and enhance domestic activities

- Autonomy in the operative aspects of policy implementation allowing delegation of responsibilities to divisions and teams

- Government policies that continuously adjust to the changing external and internal situation

- Face to face interaction between agency employees and investors, complemented by personal accountability and the implementation of safeguards against corruption

- Assessment of the outcomes of policy making to reduce risk and allow adjustments to its implementation

However, public-private coordination mechanisms, including meso-level coordination mechanisms (activities, sectors and global value chains), and organisationally successful strategic investment promotion agencies, are not sufficient for successful smart specialisation unless the policy environment is conducive to internationalisation, linking between domestic with foreign investors and GVC leaders.

\section{Policy Environment}

Smart specialisation may generate new insights and new programmes but for these to be effective will require the overall policy environment to be geared towards the generation of both foreign and domestic knowledge. Below, we outline the major policy areas that influence the internationalisation of systems of innovation in the 
EU-13 and which are the policy preconditions for the internationalisation of smart specialisation.

\section{Fostering Demand Driven FDI in R\&D\&I}

The major focus of R\&D policies in the EU-13 is on R\&D excellence, and smart specialisation provides the opportunity to work towards fostering demand-driven R\&D and facilitating the upward evolution of existing manufacturing and services. The EU-13 countries are unlikely to attract significant supply-driven R\&D in the business sector; there are few locations in the EU with the relevant science and technology infrastructure (Narula and Guimón 2009). Thus, it would be more effective to focus on fostering demand-driven $\mathrm{R} \& \mathrm{D}$, i.e. $\mathrm{R} \& \mathrm{D}$ that is related to the implementation of improved products and processes which are produced or assembled in the EU-13. However, this requires critical mass and international leverage, which, in turn, require FDI-oriented investment complemented by local investments in technology and firm-specific infrastructures. Therefore, the issue for the EU-13 countries is how to attract technology-oriented FDI and exploit it to leverage local investment in $R \& D$, especially in downstream areas.

\section{Focusing on the 'Quality' of FDI and GVCs}

This requires a shift from prioritising and attracting FDI towards a focus on the quality of subsidiary developments. CzechInvest recognised the need for a shift from focusing on FDI investments in manufacturing and blue-collar jobs towards new sectors (Software \& ICT Services, Business Support Services, Aerospace, Advanced Automotive, Industrial Machinery, Equipment and Tools, Life Sciences. Electrical Engineering/Electronics, Advanced Renewable Energy/ Cleantech, and Nanotechnology). It identified this as a 'shift from quantity to quality' (see also Filippov and Guimón 2009; Alfaro and Charlton 2007). This requires closer links between FDI, and industry and innovation policies. The tendency in the EU-13 has been to focus on FDI inflows and to ignore the R\&D\&I content of FDI, explained by the primary aim of generating employment rather than technological upgrading of the economy. However, this provides only a temporary easing of the problem since it addresses only cost competitiveness and does not resolve the issue of technology competiveness. The example of the successful policy which has been relatively successful in attracting large amounts of FDI, which has either generated or preserved jobs and is now engaged in a shift towards 'quality', i.e. technology value-added or knowledge content, is Czech Republic. Radosevic and Stancova (2015, Box1) show that this success is due largely (although not exclusively as the case of food industry shows) to its successful FDI agency, which has evolved into a development agency. The post-2008 environment has not changed Czech FDI policy priority of high-quality FDI. The global financial crisis and vulnerability of growth in CEECs have worked only to re-confirm the need for this policy orientation, which was underway in the Czech Republic-earlier than in other EU-13 countries. 


\section{Integrating FDI and Innovation Policy}

Organisational and policy separation of the promotion of innovation and FDI in the EU-13 is a major obstacle to the internationalisation of smart specialisation. This organisational and policy deficiency reduces the effects of even the most successful 'entrepreneurial discovery processes' since there are no follow-up incentives in place nor institutional structures on which to build. The internationalisation of local companies consists mainly of participation in foreign exhibitions and international R\&D support through EU funds. Also, EU-13 Embassies and delegation to foreign countries carry out promotion and economic activities in support of domestic companies to help them enter foreign markets and establish business relations. These activities are arranged in a form of business breakfast or cafe, meetings at Embassies or visits. Yet, measures to stimulate strategic subcontracting or participation of the EU-13 firms in GVCs are still weak, although the drivers of growth in the EU-13 are closely linked to export and internationalisation.

Support for technologically demanding investment projects with high added value should become a priority. ${ }^{15}$ It seems that the EU-13 have reached limits in terms of the number of MNEs investing in R\&D. Further development of such investments is limited mainly by the lack of qualified labour force, low quality of R\&D management, low level of cooperation between research institutes and MNEs, and low support for R\&D activities in large MNEs. Policy objectives should include strengthening the interaction between FDI and domestic R\&D\&I policy.

Within this process of integrating FDI and innovation policy, the ultimate step is assisting the internationalisation of local firms. Again, we would highlight the example of Czech Accelerator 2011-2014, a successful CzechInvest project which has helped develop Czech technology SMEs in foreign markets.

\section{Developing a Strategic Approach to the Internationalisation of $R \& D$}

Smart specialisation strategies are often inward oriented in their implementation despite a design related to external opportunities and constraints. This is often because regions/ countries do not have the capacities required to develop a strategic approach to internationalisation. This is particularly clear in relation to participation in the EU Horizon 2020 activities where there is not a strategic approach to international funding including funding from the EU. In many EU-13 countries, there are incentives for individuals to apply to the EU Horizon 2020 projects. However, this has not led always to optimal outcomes since much foreign-funded research is not relevant or involves only limited links with the wider research community. There is a need for a more strategic approach to the internationalisation of R\&D.

The EU-13 should try to maximise the impact on their domestic and FDI-driven innovation systems of EU and international funding instruments. The level of subsidiarity achieved through national and Horizon 2020 projects appears limited because

\footnotetext{
${ }^{15}$ For example, the Czech government has been funding the establishment of technology centres through the Framework Programme for the Support of Technology Centres and Centres of Business Support Services. These Centres are located in important industrial centres with high innovation potential and are a good example to follow.
} 
they are considered two separate channels for raising finance. Also, bilateral cooperation with non-EU countries frequently lacks an underlying or clear strategy for bilateral cooperation. Rather than increasing the funding for international cooperation, these activities should be more firmly rooted in the strategic interests of national innovation systems. This will require a paradigm shift away from providing incentives for high levels of participation in international programmes, towards a more integrated appraisal of the usefulness of international collaboration for the country's overall development. This strategic approach to international cooperation, exploiting opportunities for joint programming and cross-border cooperation and exploiting the leveraging effects of EU instruments, has yet to be developed.

\section{Strengthening and Improving Horizontal Links in the Innovation System}

Our focus so far has been on either upstream $(R \& D)$ or downstream (manufacturing and services) vertical integration. However, Fig. 1 shows that smart specialisation activities should be aimed at strengthening vertical links and also enhancing horizontal linkages, or links between upstream R\&D and downstream non-R\&D activities.

This is not a trivial task since foreign companies' $R \& D$ activity is often part of a global strategy and, hence, does not require close cooperation with domestic universities. For example, the international comparison of science industry links undertaken by Technopolis Group (2011) reveals relatively low intensity of interactions between the science and business sectors. The Czech Republic level is equal to or lower than interaction levels in other CEECs. The Technopolis Group (2011) study concludes that science-industry links would play a key role in the process of upgrading towards more knowledge-intensive activities in the Czech production system. Measures are needed to embed multinationals in local R\&D systems. These should include attracting MNEs via the bundling of competencies in research centres, strategic partnerships with universities, tax incentives for traineeships or integration in the organisation of industry-oriented $\mathrm{PhD}$ programmes. We would expect that as the quality and depth of vertical linkages improve, there will be increased opportunities for stronger horizontal linkages in innovation system. However, the outcomes are not automatic, and activities such as smart specialisation will be instrumental in identifying potential niches for both vertical and horizontal cooperation.

\section{Conclusions}

An important assumption related to this paper is that technology upgrading is highly dependent on whether countries and regions use GVCs and international R\&D networks as levers, linkages and mechanisms of learning. The key challenge for smart specialisation is how the local production stage of GVCs may become a building block of regional innovation strategy (Foray 2014).

This paper is aimed at contributing to a better understanding of inter-regional and trans-regional cooperation in the EU-13 in the context of smart specialisation. It is obvious from the discussion that internationalisation should be the sixth principle of smart specialisation strategies in addition to (1) the level ('granularity') at which priorities are identified and supported, (2) the entrepreneurial discovery process, (3) 
the temporary nature of actions, (4) inclusiveness, and (5) the need for continuous evaluation (Foray 2013). The key feature of this sixth principle is that learning and technology upgrading should follow from intensive international leveraging and linking involving all the relevant actors.

Our discussion of policy issues is underpinned by the following 'stylised facts' related to the EU-13 countries' R\&D\&I activities:

- $\quad \mathrm{R} \& \mathrm{D}$ in the EU-13 is collaborative in nature, while growth at firm level is closely related to export, FDI and vertical specialisation.

- Both the upstream and downstream parts of the innovation process (both R\&D and non-R\&D) are deeply internationalised but also weakly linked.

- A specificity of the EU-13 economies is that much of their innovation activities is non-R\&D, and the core of their technology upgrading is about the transition from production to technology capability.

- We have argued that the internationalisation of upstream (R\&D) activities in EU-13 is much more advanced than the internationalisation of downstream and non-R\&D activities.

- Smart specialisation design emphasises that internationalisation is an important activity; however, within this, the emphasis is more on upstream or R\&D activities related to Horizon 2020 than downstream activities related to GVCs.

GVCs and MNEs on their own cannot resolve all the issues, but this is not to ignore their linking and leverage potential to improve the R\&D\&I capacity of the EU-13. Their importance stems from the acknowledgement in international economics that internationalisation and innovation are inextricably linked (Altomonte et al. 2013). Finally, GVCs and FDI have been important drivers of productivity growth in the EU-13, and it is difficult to believe that the post-2008 shift in their growth model is based entirely on endogenous resources, knowledge and skills. It is important for small open economies, such as the EU-13, to explore new ways that MNEs and GVCs could be exploited as mechanisms for learning and innovation in EU-13 firms.

Smart specialisation as an ex-ante conditionality for using R\&D\&I funds represents a historic opportunity to leverage substantial EU Structural Funds enabled by foreign sources of R\&D\&I, both upstream and downstream in the value chains. Since the EU-13 countries are now fully integrated in EU R\&D\&I networks, which we have argued, and are largely upstream oriented, this paper focuses especially on downstream linkages and how smart specialisation activities could enable technology upgrading in the EU-13 via GVCs and FDI.

We highlighted three key issues: first, the choice of GVC best suited to regional R\&D\&I and manufacturing or services capacities. We presented this issue through a taxonomy that combines types of GVC activity with types of regions. We proposed this as a heuristic to frame a problem that requires in-depth and region-specific analysis. We argued also that the level at which smart specialisation should be prioritised is not individual business functions but rather activities or descriptions of technological activities within specific business functions.

Second, we investigated how firms can be assisted to 'climb the ladder' or move from process, to product, and to functional or value chain upgrading. The types of capabilities and external support required for each type of upgrading within the GVCs 
differ in different types of global value chain or different types of MNE subsidiaries. This issue is illustrated in Table 3, which combines types of upgrading with types of relationships ranging from arm's length to types of value chain relationships and forms of vertical integration via MNEs.

Third, smart specialisation is about discovering new 'ladders' or new production and market uses of existing capabilities, not originally envisaged by either the foreign or local partner. This process involves interaction between GVC lead firm and local supplier but also is shaped by infrastructural support for R\&D\&I on which firms can rely.

We considered the inter-regional and transnational dimensions of smart specialisation as integral, and we do not envisage additional steps to those already stipulated in the smart specialisation Guide for RIS3. However, we foresee several additional obstacles to smart specialisation related to choice of GVCs or attracting MNEs, in terms of technology upgrading through GVCs and in discovering new opportunities alongside existing GVCs. These barriers emerge because domestic actors need to interact with the local MNE subsidiaries or GVC subcontractors, which have limited autonomy. Also, their notions of areas providing mutual opportunities may diverge greatly from those of the MNE headquarters and other local actors. A major challenge and source of complexity related to the internationalisation of smart specialisation is how to overcome cognitive biases without established institutional systems for interaction and continuous communication with foreign actors, and in the absence of a rich policy environment to provide incentives to foreign actors to consider new options. We investigated these issues in some detail drawing on the example of CzechInvest as a successful strategic investment promotion agency that combines FDI and innovation policy tasks. However, rather than plumping for one particular organisational form that combines FDI and innovation policy issues, we consider it essential to explore the factors that can lead to organisational success in the public promotion of FDI and innovation.

We have considered several major policy areas which are an indispensable part of the policy mix for 'internationalised' smart specialisation. In particular, we highlighted the need to foster demand (as opposed to supply)-driven FDI in R\&D\&I, to focus on the 'quality' of FDI and GVCs, to integrate FDI and innovation policy, to develop a strategic approach to the internationalisation of R\&D and to strengthen and improve horizontal links in the innovation system.

In view of the complexity and novelty of this topic, we consider this paper to be primarily an agenda defining rather than resolving the problems. Nevertheless, we hope that our discussion and proposals will advance thinking about the 'internationalisation of smart specialisation' and lead to further discussion and policy advances.

Open Access This article is distributed under the terms of the Creative Commons Attribution 4.0 International License (http://creativecommons.org/licenses/by/4.0/), which permits unrestricted use, distribution, and reproduction in any medium, provided you give appropriate credit to the original author(s) and the source, provide a link to the Creative Commons license, and indicate if changes were made.

\section{References}

Alfaro, L. and Charlton, A. (2007). Growth and the quality of foreign direct investment: is all FDI equal? CEP discussion paper No 830, London School of Economics and Political Science. 
Altomonte, C., Tommaso, A., Békés, G., \& Ottaviano, G. (2013). Internationalization and innovation of firms: evidence and policy. Economic Policy, 28(76), 663-700.

Arundel, A. and Kanerva M. (2010). The 'neglected' innovators: what do they do and does it matter? Results of an analysis of the innobarometer 2007 survey No. 215, UNU MEIT, mimeo.

Arundel, A., Bordoy, C. and Kanerva, M. (2008). Neglected Innovators: how do innovative firms that do not perform R\&D innovate? Results of an analysis of the Innobarometer 2007 survey No. 215, INNO-metrics thematic paper, Brussels.

Becker, T., Daianu, D., Darvas, Z., Gligorov V., Landesmann M., Petrovic, P., Pisani-Ferry, J., Rosati, D., Sapir, A. and Weder Di Mauro, B. (2010). Whither growth in central and eastern Europe? Policy lessons for an integrated Europe, Bruegel Blueprint Series. Available at http://www.bruegel.org/.

Benáček, V. (2009). CzechInvest as an example of public administration competence. In K. Staronova \& L. Vass (Eds.), Public policy and administration: challenges and synergies (pp. 15-36). Bratislava: NISP Acee Press.

Benáček, V. (2010). Is the Czech economy a success story? The case of CzechInvest: the strategic promotion agency in Czech industrial restructuring, Comercio Internacional working paper No 101. United Nations Economic Commission for Latin America, Division of International Trade and Integration, Santiago, March, Final Report, Synthesis Report and Annexes.

Benneworth, P. and Dassen, A. (2011). Strengthening global-local connectivity in regional innovation strategies: implications for regional innovation policy. OECD regional development working papers, 2011/01, Paris: OECD, at http://dx.doi.org/10.1787/5kgc6d80nns4-en.

Cantwell, J., \& Ram, M. (2005). MNE competence-creating subsidiary mandates. Strategic Management Journal, 26, 1109-1128.

Capello, R. and Perucca, G. (2013). Do Eastern European Regions move towards an endogenous growth pattern? A diachronic perspective of regional success factors, growth-innovation-competitiveness. Fostering cohesion in central and eastern Europe (GRINCOH) project, WP1 task 3, final version, 28 February.

Carlsson, B. (2006). Internationalization of innovation systems: a survey of the literature. Research Policy, 35, 56-67.

Cass, F. (2007). Attracting FDI to transition countries: the use of incentives and promotion agencies. Transnational Corporations, 16(2), 77-122.

Damijan, J., Rojec, M., Majcen, B., \& Knell, M. (2013). Impact of firm heterogeneity on direct and spillover effects of FDI: micro evidence from ten transition countries. Journal of Comparative Economics, 41, 895-922.

Ecorys (2013). Exchange of good practice in foreign direct investment promotion. A study carried out under the framework contract ENTR/2009/033, Final report for DG enterprise \& industry, 2nd revision, Rotterdam, 4 July.

Filippov, S. and Guimón, J. (2009). From quantity to quality: challenges for investment promotion agencies, working paper series No. 057, UNU-MERIT, Maastricht.

Foray, D. (2013). The economic fundamentals of smart specialisation. Ekonomiaz, 83(2), 83-102.

Foray, D. (2014). Presentation at national peer review workshop: smart specialisation-moving forward and looking outward, 3-4 July, Dublin, Ireland.

Foray, D., Goddard, J., Goenaga Beldarrain, X., Landabaso, M., McCann, P., Morgan, K., Nauwelaers, C., \& Ortgea-Argiles, R. (2012). Guide to research and innovation strategies for smart specialisation (RIS 3), smart specialisation platform. Seville: IPTS.

Fratesi, U. (2012). Successful European regions in a global economy: a synthesis and outlook. Regional Science Policy and Practice, 4(1), 113-121.

Fu, X., Pietrobelli, C., \& Soete, L. (2011). The role of foreign technology and indigenous innovation in the emerging economies: technological change and catching-up. World Development, 39(7), 1204-1212.

Gereffi, G. and Fernandez-Stark, K. (2011). Global value chain analysis: a primer. Duke University, NC: Center on globalization, governance \& competitiveness.

Giuliani, E., Pietrobelli, C., \& Rabellotti, R. (2005). Upgrading in global value chains: lessons from Latin American clusters. World Development, 33(4), 549-573.

Gosens, J., Lu, Y., \& Coenen, L. (2015). The role of transnational dimensions in emerging economy 'technological innovation systems' for clean-tech. Journal of Cleaner Production, 86, 378-388.

Hanousek, J., Kocenda, E., \& Maurel, M. (2010). Direct and indirect effects of FDI in emerging European markets: a survey and meta-analysis. Economic Systems, 35, 301-322.

Hansen, M. and Birkinshaw, J. (2007). The innovation value chain. Harvard business review, June, pp. 121-130. 
Holland, D., Sass, M., Benáček, V., \& Gronicki, M. (2000). The determinants and impact of FDI in CEE: a comparison of survey and econometric evidence. Transnational Corporations, 9(3), 163-212.

International Monetary Fund (IMF) (2013a). German-central European supply chain-cluster report. IMF country report 13/263, August 20th.

International Monetary Fund (IMF) (2013) Trade linkages, balance sheets, and spillovers: the GermanyCentral European supply chain. Working paper prepared by Selim Elekdag and Dirk Muir, European Department, October.

Jindra, B., Dominguez Lacasa, I. and Radosevic, S. (2015). Dynamics of technology upgrading of the central and east European countries in a comparative perspective: analysis based on patent data, growthinnovation-competitiveness. Fostering Cohesion in Central and Eastern Europe (GRINCOH) project report, WP3 Task 3, P3.4., paper 2.

Johannes, S. (Ed.). (2006). Technology transfer via FDI in CEE. Theory, method of research and empirical evidence. London: Palgrave Macmillan.

Karo, E. and Kattel, R. (2015 forthcoming). Economic Development and Evolving State Capacities in Central and Eastern Europe: can 'smart specialisation' make a difference? Journal of Economic Policy Reform.

Komninos, N., Musyck, B., \& Reid, A. I. (2014). Smart specialisation strategies in south Europe during crisis. European Journal of Innovation Management, 17(4), 448-471.

Kravtsova, V., \& Radosevic, S. (2011). Are systems of innovation in Eastern Europe efficient? Economic Systems, 36(1), 109-126.

Leitner, S. M. and Stehrer R. (2014). Trade integration, production fragmentation and performance in Europe blessing or curse? A comparative analysis of the new member states and the EU-15, The Vienna institute for international economic studies, growth-innovation-competitiveness. Fostering Cohesion in Central and Eastern Europe (GRINCOH) project, WP5, Task 2, P2.5. Final: May 30th.

Majcen, B., Radosevic, S., \& Rojec, M. (2009). Nature and determinants of productivity growth of foreign subsidiaries in central and east European countries. Economic Systems, 33(2), 168-184. June.

Marin, A., \& Arza, V. (2009). The role of MNEs in developing countries: from technology diffusion to international involvement. In L. Bengt-Ake, K. J. Joseph, C. Chaminade, \& J. Vang-Lauridsen (Eds.), Handbook of innovation systems and developing countries - building domestic capabilities in a global setting. Cheltenham: Edward Elgar.

Marin, A., \& Giuliani, E. (2011). MNC Subsidiaries' position in global knowledge networks and local spillovers: evidence from Argentina. Innovation and Development, 1(1), 91-114.

Marin, A., \& Sasidharan, S. (2010). Heterogeneous MNC ssubsidiaries and technological spillovers: explaining positive and negative effects in India. Research Policy, 39(9), 1227-1241.

Mathews, J. A. (2002). Competitive advantages of the latecomer firm: a resource-based account of industrial catch-up strategies. Asia Pacific Journal of Management, 19, 467-488.

McGowan, F., Radosevic, S., \& von Tunzelmann, N. (Eds.). (2004). The emerging industrial structure of the wider Europe. London: Routledge.

McGrew, A. G., \& Lewis, P. G. (Eds.). (1992). Global politics: globalization and the nation state. Cambridge: Polity Press.

Nakrosis, V. (2015). Policy transfer in the pre- and post-accession period: experience of the new EU member states, Vilnius University, TSPMI/ Institute of International Relations and Political Science. Available at https://www.academia.edu/10487811/POLICY_TRANSFER_IN_THE_PRE-_AND_POSTACCESSION_PERIOD_EXPERIENCE_OF_THE_NEW_EU_MEMBER_STATES.

Narula, R. and Guimón, J. (2009). The contribution of multinational enterprises to the upgrading of national innovation systems in the EU new member states: policy implications, organisation for economic cooperation and development (OECD), global forum on international investment OECD investment division, Paris: OECD.

Organisation for Economic Cooperation and Development (OECD). (2013). Global value chains, development and competitiveness. Sharing policy practices. Discussion paper, 19 March. Paris: OECD.

Pavlınek, P., \& Zenka, J. (2011). Upgrading in the automotive industry: firm-level evidence from central Europe. Journal of Economic Geography, 11, 559-586.

Pavlinek, P., Zenka J. and Zizalova, P. (2010). Functional upgrading through research and development in the Czech automotive industry. XXII sjezd Ceske geograficke spolecnosti, Ostrava, http://konference.osu.cz/cgsostrava2010.

Pietrobelli, C., \& Rabellotti, R. (2011). Global value chains meet innovation systems: are there learning opportunities for developing countries? World Development, 39(7), 1261-1269.

Płoszaj, A. and Olechnicka, A. (2015). Running faster or measuring better? How is the R\&D sector in Central and Eastern Europe catching up with Western Europe? Paper No. 3.06, growth-innovation-competitiveness. Fostering Cohesion in Central and Eastern Europe (GRINCOH) project, www.grincoh.eu. 
Radosevic, S. (2011). Science-industry links in CEE and CIS: conventional policy wisdom facing reality. Science and Public Policy, 38(5), 365-378.

Radosevic, S., \& Lepori, B. (2009). Public research funding systems in central and eastern Europe: between excellence and relevance, introduction to special issue. Science and Public Policy, 36(9), 659-666.

Radosevic, S., \& Sadowski, B. (Eds.). (2004). International industrial networks and industrial restructuring in central and Eastern Europe. Dordrecht: Kluwer Academic Publishers.

Radosevic, S., \& Ciampi Stancova, K. (2015). External dimension of smart specialisation: opportunities and challenges for trans-regional and transnational collaboration in the EU-13, EC, JRC technical reports, S3 working paper series, No 09/2015.

Radosevic, S. and Yoruk, E. (2011). SAPPHO revisited: factors of innovation success in knowledge-intensive enterprises in Central and Eastern Europe. DRUID working paper No. 12-11. Available at http://www3. druid.dk/wp/20120011.pdf.

Radosevic, S., \& Yoruk, E. (2014). Are there global shifts in world science base? Analysis of catching up and falling behind of world regions. Scientometrics, 101(3), 1897-1924. doi:10.1007/s11192-014-1344-1.

Radosevic, S., Savic, M., \& Woodword, R. (2010). Knowledge based entrepreneurship in central and Eastern Europe: results of a firm level based survey. In F. Malerba (Ed.), Knowledge-intensive entrepreneurship and innovation systems (pp. 198-218). London: Routledge.

Radosevic, S., Havas, A., Korosteleva, J., Yoruk, E., Varga, A., Dominguez Lacasa, I., Titze, M., Jindra, B. (2015). Technology upgrading and innovation policy in Central and Eastern Europe. Synthesis report for WP3: innovation, entrepreneurship and industrial dynamics: final report, GRINCOH (GrowthInnovation-Competitiveness. Fostering Cohesion in Central and Eastern Europe) project.

Randma-Liiv, T., Nakrošis, V. and György, H. (2011). Public sector organization in Central and Eastern Europe: from agencification to de-agencification. Transylvanian Review of Administrative Sciences, Special Issue, pp. 160-175.

Ropera, S., \& Arvanitis, S. (2012). From knowledge to added value: a comparative, panel-data analysis of the innovation value chain in Irish and Swiss manufacturing firms. Research Policy, 41(6), 1093-1106.

Rozeik, A. (2011). The growth and global integration of the CEEC automotive industry. Unpublished $\mathrm{PhD}$ Thesis, University College London, School of Slavonic and East European Studies.

Rugman, A., Verbeke, A., \& Yuan, W. (2011). Re-conceptualizing Bartlett and Ghoshal's classification of national subsidiary roles in the multinational enterprise. Journal of Management Studies, 48(2), 253-277.

Steinfeld, E. S. (2004). China's shallow integration: networked production and the new challenges for late industrialization. World Development, 32(11), 1971-1987.

Szalavetz, A. (2012). Micro-level aspects of knowledge-based development: measuring quality-based upgrading in MNCs' Hungarian subsidiaries. International Journal of Knowledge-Based Development, 3(4), 313-330.

Szalavetz, A. and Sass, M. (2011). Insertion into global value chains and vulnerability to crisis. Institute of economics and institute for world economics of HAS, first draft of the 17th of September, mimeo.

Tang, M., \& Hussler, C. (2013). Betting on indigenous innovation or relying on FDI: the Chinese strategy for catching-up. Technology in Society, 33, 23-35.

Technopolis Group (2011). International audit of research, development \& innovation in the Czech Republic, final report. Synthesis report and annexes.

Yoruk, D.-E. (2012). Firm-level upgrading in low- and medium-technology industries in emerging markets: the role of learning networks. Unpublished $\mathrm{PhD}$ thesis, science and technology policy research, University of Sussex, September. 